\title{
LITERASI BACA TULIS DAN INOVASI KURIKULUM BAHASA
}

\author{
Vivi Indriyani", M. Zaim, Atmazaki, Syahrul Ramadhan
}

Pascasarjana, Universitas Negeri Padang, Indonesia

*Corresponding author: vivi.indriyani93@gmail.com

\section{INFORMASI ARTIKEL}

\section{Kata Kunci: \\ Inovasi \\ Kurikulum \\ Literasi \\ Menulis \\ Membaca}

Sejarah Artikel

Diterima: $12 / 3 / 2019$

Direvisi: $7 / 6 / 2019$

Disetujui: $10 / 6 / 2019$

Tersedia Daring: 28/6/2019

Kurikulum pendidikan di Indonesia mengalami perubahan pada tahun 2013. Perubahan tersebut merupakan usaha untuk meningkatkan mutu pendidikan di Indonesia. Pada pembelajaran bahasa Indonesia, kurikulum yang digunakan adalah berbasis teks. Beberapa tahun kemudian, untuk mewujudkan visi dan misi agar masyarakat dapat beradaptasi dengan kemajuan pengetahuan dan teknologi, pemerintah mengeluarkan kebijakan tentang Gerakan Literasi Sekolah (GLS) dan diperbarui dengan Gerakan Literasi Nasional (GLN). Penelitian ini bertujuan untuk mengetahui kegiatan literasi yang dilakukan di sekolah dan melihat respon siswa setelah dilaksanakan kegiatan literasi. Penelitian ini merekomendasikan untuk mempertimbangkan literasi sebagai inovasi kurikulum di sekolah. Penelitian ini merupakan penelitian deskriptif dengan teknik wawancara terstruktur dan teknik pengumpulan angket. Instrumen yang digunakan adalah pedoman wawancara dan lembar kuesioner. Wawancara dilakukan dengan tujuh orang guru Bahasa Indonesia di Sumatera Barat dan Angket diisi oleh 30 orang siswa. Hasil penelitian menunjukkan bahwa dalam pelaksanaannya, literasi tidak dilaksanakan dengan aturan yang ditetapkan. Tujuan dari literasi tersebut juga tidak tercapai dengan mestinya. Dalam pelaksanaannya, kurikulum dan literasi seolah-olah merupakan dua hal yang berbeda dan pelaksanaan yang tidak sejalan. Padahal, kegiatan pembelajaran yang dilakukan merupakan kegiatan literasi. Khusus pada pembelajaran bahasa, literasi yang dilakukan adalah literasi baca dan tulis.

\section{ABSTRACT}

Keywords:

Innovation

Curriculum

Literacy

Write

Read
The education curriculum in Indonesia changed in 2013. The change was an attempt to improve the quality of education in Indonesia. In learning Indonesian, the curriculum used is text based. Several years later, to realize the vision and mission so that the community can adapt to the advancement of knowledge and technology, the government issued a policy on the School Literacy Movement and was updated with the National Literacy Movement. This study aims to determine the literacy activities carried out in schools and see student responses after literacy activities are carried out. This study recommends considering literacy as a curriculum innovation in schools. This research is a descriptive study with structured interview techniques and questionnaire collection techniques. The instruments used were interview guides and questionnaire sheets. Interviews were conducted with seven Indonesian Language teachers in West Sumatra and questionnaires filled by 30 students. The results of the study show that in its implementation, literacy is not carried out with the rules set. The purpose of literacy is also not achieved properly. In its 
implementation, the curriculum and literacy are as if they are two different things and the implementation is not in line. In fact, the learning activities carried out are literacy activities. Especially in language learning, literacy is done by reading and writing literacy.

Copyright@2019, Vivi Indriyani*, M. Zaim, Atmazaki, Syahrul Ramadhan This is an open access article under the CC-BY-3.0 license
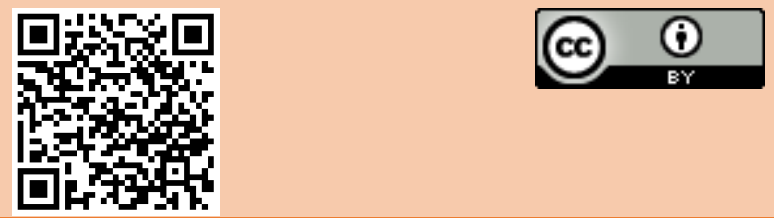

\section{PENDAHULUAN}

Perkembangan ilmu pengetahuan dan teknologi, menciptakan masyarakat yang terus berupaya untuk meningkatkan kemampuannya di dalam dunia pendidikan. Pendidikan merupakan wujud dari suatu kemajuan. Suatu masyarakat yang maju adalah ditandai dengan majunya sektor pendidikan yang berkualitas. Pendidikan yang berkualitas tersebut ditandai salah satunya dengan masyarakat yang literat.

Untuk memajukan pendidikan, salah satu upaya yang dapat dilakukan adalah dengan inovasi atau perubahan kurikulum. Perlunya perubahan tersebut dengan tujuan untuk mengatasi kebutuhan yang baru muncul sebagai dampak dari kemajuan zaman (Psifidou, 2009). Pembaharuan berkelanjutan kurikulum juga dilakukan agar kurikulum tetap dinamis dan lebih responsif terhadap kebutuhan siswa saat ini dan di masa depan (Kırkgöz, 2009). Hal itu sesuai dengan salah satu sifat kurikum yang tidak stagnan tetapi sering berubah untuk menyesesuaikan dengan modernisasi (Nhlapo \& Maharajh, 2017).

Perubahan kurikulum harus bertujuan untuk meningkatkan kurikulum (Uztozun \& Troudi, 2015). Peningkatan kurikulum (juga sering disebut sebagai pembaharuan kurikulum atau reformasi) di tingkat seluruh lembaga, adalah pekerjaan yang menantang (ClasquinJohnson, 2016). Faktor-faktor perubahan kurikulum antara lain, perubahan kebijakan, munculnya teknologi baru dan globalisasi (Aydin, Ozfidan, \& Carothers, 2017). Memastikan akuisisi pengetahuan siswa dan keterampilan yang diperlukan untuk beradaptasi dengan perubahan kondisi dunia menentukan dasar untuk inovatif upaya dalam bidang kurikulum (Bumen, Cakar, \& Yildiz, 2014).

Kurikulum memainkan peran penting dalam pengorganisasian, mengarahkan, mentransmisikan pengetahuan dan membimbing kegiatan belajar (Young, 2014); (Longhurst, 2016); (Rumahlatu, Huliselan, \& Takaria, 2016). Perubahan kurikulum adalah kompleks, beragam, dan proses berulang, di mana ide dibuat menjadi kebijakan, diubah menjadi perilaku, dan dinyatakan sebagai tindakan sosial (Hubball \& Burt, 2014). Cara yang bermanfaat untuk menjelaskan apakah kurikulum berhasil atau tidak adalah untuk memeriksa konsep ketepatan kurikulum (Dusenbury, Brannigan, Falco, \& Hansen, 2003).

Manfaat mengevaluasi, merevisi, atau mereformasi kurikulum secara berkala dilakukan untuk memastikan bahwa kebutuhan peserta didik ditangani secara memadai (Jackson, 2005). Akan tetapi, keberhasilan penerapan kurikulum yang diperbarui jauh lebih menantang, walaupun tahap awal desain ulang kurikulum relatif mudah (Cooper, 2017). Hal tersebut merupakan perbedaan antara kurikulum yang dirancang dan kurikulum yang disahkan (Barnet \& Coate, 2015).

Kurikulum dapat didefinisikan bukan hanya sekedar konten informasi dari program, tetapi lebih sebagai program pengalaman belajar yang lebih luas (Clasquin-Johnson, 2016). 
Desain dan pengembangan kurikulum adalah salah satu yang pertama dalam proses belajar mengajar karena menginformasikan apa harus diajarkan dan dipelajari di sekolah-sekolah. Dalam desain kurikulum, kebijakan, sasaran, misi, dan visi pendidikan suatu negara ditafsirkan dan diubah menjadi tujuan umum, yang dapat dengan mudah ditransfer oleh guru sekolah tujuan instruksional dan standar pembelajaran (Nhlapo \& Maharajh, 2017). Oleh karena itu, guru memiliki peran sentral dalam menjalankan kurikulum pada proses pembelajaran di sekolah (Ramberg, 2014); (Uztozun \& Troudi, 2015).

Guru dapat menjadi agen utama perubahan kurikulum (Rekkor, Ümarik, \& Loogma, 2013); (Burns, Yendol-Hoppey, \& Jacobs, 2015). Perubahan kurikulum dapat ditanggapi oleh guru dengan cara-cara berikut: mereka abaikan, tahan, adopsi atau sesuaikan kurikulum resmi (Clasquin-Johnson, 2016). Jika guru dipahami sebagai aktor dalam proses reformasi, mereka mengambil bagian dalam pengembangan kebijakan (Hoydalsvik, 2017). Mereka kemudian menerjemahkan ide ke dalam tindakan dan perspektif teoretis ke dalam praktik-praktik baru dan menerjemahkan gagasan tentang bagaimana mengembangkan kurikulum untuk mata pelajaran multidisiplin dalam praktek (Hoydalsvik, 2017). Guru juga dapat menentukan konten dan metode yang tepat dalam pelaksanaan kurikulum (Ramberg, 2014).

Perubahan kurikulum di Indonesia selalu dilakukan inovasi secara berkala. Perubahan kurikulum tersebut bertujuan untuk memajukan pendidikan dan memperbaiki pendidikan sebelumnya. Walaupun kurikulum telah berubah, tetapi revisi terus dilakukan. Pada tahun 2013, di Indonesia, Kurikulum 2013 diberlakukan, pada tahun 2014 dan 2016 dilakukan revisi pada kurikulum pada aspek-aspek tertentu contohnya Kompotensi Inti dan Kompe-tensi Dasar pada mata pelajaran.

Di Indonesia, sejalan dengan perubahan Kurikulum pada tahun 2013, pemerintah mencanangkan program Gerakan Literasi Sekolah (GLS) untuk meningkatkan literasi siswa. Pencanangan kegiatan GLS merupakan langkah awal yang baik dalam upaya untuk menjadikan masyarakat literat. GLS merupakan kebijakan dari Kementerian Pendidikan dan Kebudayaan untuk mewujudkan visi agar masyarakat dapat mengadaptasi kemajuan teknologi dan keterbaharuan. Pada tahun 2018 pemerintah berusaha untuk menjadikan literasi sebagai prioritas nasional dengan dicanangkan Gerakan Literasi Nasional (GLN). Gerakan tersebut tidak hanya ditujukan hanya untuk siswa saja, tetapi ditujukan untuk masyarakat pada umumnya.

Setelah dicanangkan Gerakan Literasi Sekolah (GLS) dan Gerakan Literasi Nasional (GLN), beberapa sekolah telah melaksanakan kegiatan tersebut dengan melakukan kegiatan membaca 15 menit sebelum pembelajaran dimulai. Bacaan yang dibaca oleh siswa beragam dan hasil bacaan tersebut ditulis berupa ulasan di dalam buku harian. Berdasarkan kegiatan literasi tersebut, kurikulum pembelajaran dan literasi dilakukan secara terpisah dan sejalan. Pelaksanaan kegiatan literasi menempatkan literasi sebagai pelengkap dalam pelaksanaan kurikulum. Seharusnya, literasi dan pembelajaran yang dilakukan bukan sesuatu yang terpisah tetapi dua hal yang dapat dilakukan bersama-sama. Menempatkan kurikulum literasi dalam kehidupan siswa menjadi lebih berguna dan relevan untuk kehidupan pada saat ini (Petrone, 2013).

Literasi adalah hak asasi manusia yang fundamental untuk dapat meningkatkan kehidupan seseorang mencapai tujuan pribadi, sosial, pekerjaan, pendidikan, membuka peluang sosial, dan integrasi ekonomi dan politik (Rahanu et al., 2016) (Pinto, Boler, \& Norris, 2007). Literasi sangat penting bagi manusia untuk perkembangan sosial dan mengubah kehidupan untuk meningkatkan kesehatan seseorang, penghasilan seseorang, dan hubungan seseorang dengan dunia (UNESCO, 2015). Teeuw menyatakan bahwa bangsa yang literasi masyarakatnya masih rendah akan mengalami peradapan yang suram (Suryaman, 2015). Untuk itu, membangun masyarakat literat harus menjadi prioritas utama di antara prioritas-prioritas utama 
lainnya. Menjadikan literasi sebagai prioritas nasional adalah wujud untuk membentuk masyarakat yang literat (Pinto et al., 2007).

Literasi adalah dasar dalam pembentukan kepribadian multi-berpendi-dikan. Kurikulum nasional menempatkan penting tugas untuk sekolah dengan meramalkan tujuan pendidikan umum dan persyaratan publik, untuk mengembangkan kompetensi literasi siswa (Tavdgiridze, 2016). Melihat kehidupan dan dunia tercermin dalam kurikulum sekolah, kurikulum literasi harus berfungsi untuk membantu siswa memenuhi tuntutan yang semakin kompleks di dunia (Petrone, 2013).

Kurikulum literasi sering diterapkan di sekolah untuk mewujudkan konstruk literasi antitesis sebagai keterampilan "otonom" (Purcell-Gates et al., 2012). Maksudnya, literasi diasumsikan sebagai satu set keterampilan yang netral, dekontekstual yang dapat diterapkan secara universal (Street, 2003). Akan tetapi, pembuat kebijakan pendidikan masih banyak yang bergantung pada konsep literasi yang hanya menyediakan keterampilan untuk memperkuat daya saing ekonomi nasional (Pinto et al., 2007). Hal itu tercermin pada kegiatan literasi yang hanya dilaksanakan di sekolah, seharusnya untuk menciptakan praktik literasi yang lebih inklusif, kita harus memahami hubungan praktek literasi dengan wacana, keluarga, dan lingkungan masyarakat (Rogers, Tyson, \& Marshall, 2000).

Secara umum, literasi diartikan sebagai kemampuan membaca dan menulis (Solikhah, 2015). Istilah "literasi" memiliki makna meluas dari waktu ke waktu. Literasi saat ini tidak hanya diartikan sebagai kemampuan membaca dan menulis tetapi memiliki makna dan implikasi dari keterampilan membaca dan menulis dasar ke pemerolehan dan manipulasi pengetahuan melalui teks tertulis, dari analisis metalinguistik unit gramatikal ke struktur teks lisan dan tertulis, dan dampak sejarah manusia ke konsekuensi filosofis dan sosial pendidikan barat (Musfiroh \& Listyorini, 2016). Literasi mencakup berbagai jenis keterampilan seperti membaca, menulis, memproses informasi, ide dan pendapat, pengambilan keputusan dan pemecahan masalah (Tavdgiridze, 2016). Literasi juga melibatkan lebih banyak tindakan dan terhubung dengan pembentukan sikap, nilai, perasaan, hubungan, struktur kekuasaan, dan aspek kontekstual (Perry \& Homan, 2014).

Literasi telah lama identik dengan pembelajaran, sebagai tanda seorang yang berpendidikan, berpengetahuan, dan berbudaya (McGowan, 2018). Namun, literasi dalam bahasa telah dikaitkan dalam arti sempit untuk mengembangkan tata bahasa, ejaan dan tanda baca yang benar, dan kemampuan untuk menulis esai yang kompeten. Pemahaman literasi akademis yang lebih luas yang mencakup berbagai konteks akademis adalah 'kemampuan berkomunikasi secara kompeten dalam komunitas wacana akademik (Wingate, 2012).

Kemampuan literasi bahasa siswa, diuji dengan mengukur aspek memahami, meggunakan, dan merefleksikan hasil membaca dalam bentuk tulisan. Berdasarkan uji literasi yang dilakukan oleh beberapa lembaga, literasi membaca dan menulis siswa Indonesia perlu ditingkatkan. Rendahnya literasi siswa Indonesia, dapat dilihat dari data berikut. Pertama, berdasarkan data PIRLS pada tahun 2011, Indonesia berada di peringkat 45 dari 48 negara yang dievaluasi (PIRLS, 2011). Kedua, berdasarkan data PISA pada tahun 2015, Indonesia berada di peringkat 64 dari 70 negara yang dievaluasi (OECD, 2016). Ketiga, berdasarkan nilai rerata, terjadi peningkatan nilai PISA Indonesia di tiga kompetensi yang diujikan, peningkatan terbesar terlihat pada kompetensi sains dan matematika, sedangkan kompetensi membaca dan menulis belum menunjukan peningkatan yang signifikan dari tahun 2012 ke tahun 2015 .

Berdasarkan penjelasan tersebut, literasi siswa perlu ditingkatkan terutama literasi baca tulis. Selain diketahui melalui uji literasi yang telah dilakukan beberapa lembaga, perlu mengetahui bagaimana pelaksanaan literasi yang telah diterapkan oleh sekolah. Selain itu, perlu diketahui juga hasil dari pelaksanaan literasi tersebut pada aspek mendasar melalui respon 
siswa. Hal itu bertujuan agar perbaikan dapat dilakukan, terutama pada perubahan kurikulum berdasarkan kebijakan yang diberlakukan.

Berdasarkan hal tersebut, penelitian ini bertujuan untuk mengetahui kegiatan literasi yang telah dilakukan di sekolah dan melihat respon siswa setelah dilaksanakan kegiatan literasi. Hasil penelitian tersebut bertujuan untuk mengetahui posisi literasi pada kurikulum, khususnya bahasa.

\section{METODE}

Penelitian ini merupakan penelitian deskriptif. Penelitian ini dilakukan dengan teknik wawancara terstruktur dan teknik pengumpulan angket. Instrumen yang digunakan adalah pedoman wawancara dan lembar kuesioner. Pedoman wawancara digunakan sebagai pedoman untuk mewawancarai guru perihal pelaksanaan Gerakan Literasi Sekolah (GLS) ditempat guru tersebut mengajar, sedangkan angket digunakan untuk mengetahui dampak dari GLS terhadap siswa. Sumber data didapatkan dari Guru Mata Pelajaran Bahasa Indonesia di Sumatera Barat yang berjumlah tujuh orang guru, sedangkan angket diisi oleh siswa di salah satu sekolah, yaitu siswa SMP Negeri 31 Padang yang berjumlah 30 orang siswa. Data dianalisis dengan mendeskripsikan temuan yang diperoleh melalui hasil wawancara dan angket. Data wawancara dideskripsikan dengan menjabarkan jawaban dari narasumber, sedangkan data angket dideskripsikan melalui statistik deskriptif.

\section{HASIL DAN PEMBAHASAN}

Data penelitian ini didapatkan dengan melakukan wawancara dengan Guru Mata Pelajaran Bahasa Indonesia di Sekolah tingkat SMP dan SMA di Sumatera Barat. Wawancara dilakukan dengan mengajukan pertanyaan yang langsung di jawab oleh guru. Pertanyaan yang diajukan sebanyak dua pertanyaan. Pertanyaan tersebut antara lain; (1) Bagaimana pelaksanaan Gerakan Literasi Sekolah (GLS) di sekolah tempat Bapak/Ibu mengajar? (2) Bagaimana pelaksanaan literasi di kelas yang Bapak/ Ibu ajar pada pembelajaran Bahasa Indonesia. Hasil wawancara tersebut dijabarkan sebagai berikut.

Pertama, di SMA N 7 Padang, Gerakan Literasi Sekolah dilakukan dengan mewajibkan siswa membaca buku di rumah. Buku yang dibaca tersebut ditentukan oleh guru. Buku yang telah dibaca, dibuat laporan bacaan dengan format yang telah ditentukan. Laporan tersebut, dibuat dengan menggunakan tulisan tangan. Pelaksanaan kegiatan literasi pada pembelajaran bahasa tidak ada kegiatan khusus, karena kegiatan GLS sudah merupakan kegiatan literasi membaca dan menulis. Jadi GLS yang dilakukan sudah merupakan kegiatan literasi bahasa.

Kedua, di SMA N 1 Painan, Gerakan Literasi Sekolah dilakukan dengan membaca buku apa saja selama 15 menit pada awal pembelajaran. Fakta menunjukkan bahwa GLS tersebut tidak berjalan sesuai dengan kebijakan yang ditetapkan. Literasi pada pembelajaran Bahasa Indonesia dilakukan berdasarkan Kompetensi Inti dan Kompetensi Dasar yang telah diatur dalam silabus pembelajaran. Pada awal pembelajaran, siswa diwajibkan untuk membaca buku, baik berupa buku ilmiah atau buku cerita seperti novel. Pada mid semester dan akhir semester, siswa harus menyerahkan hasil ringkasan atau pokok-pokok penting dari buku yang dibaca.

Ketiga, di SMA N 1 Batang Kapas, literasi di sekolah ini belum ada kebijakan maupun pelaksanaan yang telah dilakukan, baik Gerakan Literasi Sekolah maupun literasi pada pembelajaran bahasa Indonesia.

Keempat, di SMP N 12 Padang, Gerakan Literasi Sekolah dilakukan pada hari senin sampai kamis. Pelaksanaan literasi tersebut dengan membaca buku apa saja, asal jangan komik, 20 menit sesudah istirahat. Pelaksanaan kegiatan membaca tersebut dilakukan pada pukul 
10.20 - 10-40 WIB. Tidak ada kegiatan literasi khusus pada pembelajaran bahasa. Akan tetapi, untuk pelaksanaan GLS dilakukan oleh guru mata pelajaran bahasa Indonesia. Guru bahasa Indonesia tersebut memiliki tugas mengawasi dan mengisi laporan pada buku GLS setiap hari, sesudah siswa membaca.

Kelima, di SMP N 20 Padang, Gerakan Literasi Sekolah dilakukan dengan aturan berikut, setiap selasa membaca Al-Quran, rabu membaca buku apa saja, kamis melaporkan hafalan ayat, jumat literasi di lapangan dengan pelaksanaan kultum. GLS dilakukan di 15 menit sebelum waktu pembelajaran dimulai. Kegiatan literasi membaca buku yang dilakukan pada hari rabu, dilakukan dengan membaca buku apa saja, tetapi diutamakan buku cerita. Pelaksanaan GLS dimonitoring oleh guru yang mengajar pada jam pembelajaran pertama. Pada pembelajaran Bahasa Indonesia, tidak ada kegiatan khusus yang dilakukan.

Keenam, di SMP N 31 Padang, Gerakan Literasi Sekolah dilakukan dengan mencanangkan wajib membaca selama 15 menit sebelum dimulainya jam pelajaran pertama. Selain pelaksanaan membaca, siswa dan guru yang mengajar akan melakukan kegiatan tanya jawab perihal bacaan yang telah dibaca. Siswa juga melaksanakan penulisan jurnal bacaan berdasarkan buku yang dibaca, baik di sekolah, di perpustakaan, maupun di rumah. Pelaksanaan gerakan literasi sekolah ini, baru pada tahap pembiasaan, yaitu dengan tujuan menumbuhkan minat baca serta memberikan pembiasaan membaca siswa setiap hari. Pada pembelajaran Bahasa Indonesia, tidak ada kegiatan khusus yang dilakukan.

Ketujuh, di SMP N 2 Sijunjung, Gerakan Literasi Sekolah dilakukan pada 20 menit sebelum jam pelajaran dimulai. GLS dilakukan pada hari selasa sampai kamis. Kegiatan literasi dilakukan dengan membaca buku apa saja yang tidak mengandung hal negatif. Tujuan kegiatan literasi ini adalah untuk menumbuhkan minat siswa agar giat membaca. Pada kegiatan pembelajaran bahasa Indonesia, literasi pada tingkat SMP ada pada kelas VIII dan IX. Hal itu sesuai dengan Kompetensi Inti dan Kompetensi Dasar. Pada kelas VIII siswa mempelajari teks ulasan dengan mengulas bacaan. Pada tingkat ini, siswa diminta mengulas cerita pendek yang dibaca. Pada kelas IX, siswa telah diminta untuk membaca novel dan membuat laporan dari novel yang dibaca.

Berdasarkan hasil wawancara tersebut, dapat disimpulkan hampir setiap sekolah yang diwawancara telah melaksanakan kegiatan Gerakan Literasi Sekolah. Untuk kegiatan yang dilakukan hampir sama, yaitu membaca buku dan membuat laporan dari buku yang dibaca. Akan tetapi, untuk pembelajaran bahasa tidak ada kegiatan literasi yang dilakukan. Berdasarkan hal tersebut, dapat disimpul-kan bahwa literasi yang dimaksudkan pada GLS pada pelaksanaan di sekolah objek penelitian, memiliki makna yang terbatas, yaitu kegiatan membaca buku. Padahal berdasarkan pengertian literasi, literasi memiliki arti yang luas dan kegiatan literasi dapat beragam, tidak hanya literasi membaca dan menulis, tetapi juga literasi numerasi, literasi sains, literasi finansial, digital, literasi budaya dan lingkungan dan jenis-jenis literasi lainnya.

Setelah kebijakan literasi diberlakukan, dan sekolah mulai melaksanakan kegiatan tersebut, maka akan muncul dampak terhadap pendidikan. Untuk mengetahui dampak tersebut, data diperoleh dari angket yang telah diisi oleh tiga puluh orang siswa yang dipilih secara acak. Hasil dari data angket yang didapat, butir pernyataan dikelompokan menjadi beberapa poin berikut. (1) dampak terhadap penggunaan buku di perpustakaan sekolah, (2) buku bacaan yang paling diminati, dan (3) manfaat dari membaca. Hasil dari penelitian tersebut, dijabarkan sebagai berikut.

Hasil dari angket yang diisi siswa mengenai penerapan literasi sekolah untuk poin perpustakaan menunjukan bahwa dari 30 orang siswa, $40 \%$ atau 12 siswa sering mengunjungi perpustakaan untuk membaca dan $60 \%$ atau 18 siswa kadang-kadang mengunjungi perpustakaan untuk membaca. Berdasarkan peminjaman buku bacaan, $77 \%$ atau 23 orang siswa sering meminjam buku bacaan di perpustakaan, dan 23\% atau 7 siswa kadang-kadang 
meminjam buku bacaan di perpustakaan. Berdasarkan kebutuhan, sebanyak $83 \%$ atau 25 orang siswa menyatakan bahwa buku di perpustakaan sesuai dengan kebutuhan siswa, dan $17 \%$ atau 5 siswa menyatakan bahwa buku di perpustakaan kurang sesuai dengan kebutuhan.

Berdasarkan tingkat kecendrungan buku yang dibaca, diuraikan sebagai berikut. Dari 30 orang siswa, $80 \%$ atau 24 orang siswa menyukai membaca buku pelajaran, dan sebanyak $20 \%$ atau 6 siswa kurang menyukai membaca buku pelajaran. 93\% atau 28 siswa menyukai membaca karya sastra, dan 7\% atau 2 siswa kurang menyukai membaca karya sastra. Berbeda dengan minat membaca karya sastra, 60\% atau 18 siswa menyukai membaca surat kabar, dan $40 \%$ atau 12 siswa kurang menyukai membaca surat kabar.

Berdasarkan butir pernyataan mengenai manfaat membaca diuraikan sebagai berikut. Sebanyak $93 \%$ atau 28 orang siswa menyatakan bahwa membaca bermanfaat untuk menambah ilmu pengetahuan dan $7 \%$ atau 2 siswa menya-takan bahwa membaca kurang bermanfaat untuk menambah ilmu pengetahuan. Sebanyak sebanyak $87 \%$ atau 26 orang siswa sering membaca untuk memenuhi kewajiban dan $13 \%$ atau 4 siswa kadang-kadang membaca untuk memenuhi kewajiban. Sebanyak 90\% atau 27 orang siswa sering membaca untuk membuat tugas yang diberikan guru dan $10 \%$ atau 3 siswa kadang-kadang membaca untuk membuat tugas yang diberikan guru. Sebanyak $80 \%$ atau 24 orang siswa sering menghabiskan waktu luang dengan membaca dan 20\% atau 6 siswa kadang-kadang menghabiskan waktu luang dengan membaca. Sewaktu di sekolah, sebanyak $76 \%$ atau 23 orang siswa sering membaca buku ketika guru tidak masuk kelas dan 24\% atau 6 siswa kadang-kadang membaca buku ketika guru tidak masuk kelas. Dari segi kebermanfaatan, sebanyak $100 \%$ atau 30 siswa menyatakan bahwa membaca sangat mempengaruhi dalam peningkatan pengetahuan.

\section{PEMBAHASAN}

Literasi diasumsikan sebagai satu set keterampilan yang netral, dekonteks-tual yang dapat diterapkan secara universal (Street, 2003). Literasi dapat mencakup tidak hanya literasi membaca dan menulis, tetapi juga literasi numerasi, literasi sains, literasi finansial, digital, literasi budaya dan lingkungan dan jenis-jenis literasi lainnya. Berdasarkan jenis literasi tersebut, dapat disimpulkan bahwa semua kegiatan yang dilakukan pada kegiatan pembelajaran di sekolah merupakan kegiatan literasi. Akan tetapi, pada Gerakan Literasi Sekolah (GLS) yang telah dilaksanakan di sekolah berdasarkan kebijakan Kemendikbud lebih difokuskan pada kegiatan literasi membaca dan menulis. Kegiatan tersebut dilaksanakan pada sekolah yang diteliti. Kegiatan yang dilakukan tersebut, menjadikan literasi memiliki arti sempit, yaitu mencakup membaca dan menulis (Solikhah, 2015).

Berdasarkan wawancara yang dilakukan, guru menyatakan bahwa pada kegiatan pembelajaran Bahasa tidak ada dilakukan kegiatan literasi. Pernyataan tersebut tidaklah benar, bahwa pada kegiatan pembelajaran bahasa Indonesia, pada Kurikulum 2013 berbasis teks merupakan suatu kegiatan literasi yang kompleks. Berdasarkan Kompetensi Inti dan Kompetensi Dasar, tujuan pembelajaran yang diharapkan adalah siswa mampu memahami dan menulis teks. Memahami bacaan merupakan suatu kegiatan literasi membaca.

Menjadikan literasi sebagai kurikulum merupakan suatu hal yang patut dipertimbangkan. Hal itu disebabkan karena, literasi dan kegiatan pembelajaran bukan merupakan suatu hal yang berbeda, tetapi suatu kesatuan yang dilaksanakan secara bersama. Pada pembelajaran bahasa, siswa melakukan kegiatan literasi membaca dan menulis. Pada pembelajaran metematika, siswa melakukan kegiatan literasi numerasi, dan begitu juga untuk literasi lainnya.

Rivers menyatakan bahwa, "Sebagai guru bahasa, kami adalah guru yang paling beruntung, semua mata pelajaran adalah milik kami. Apa pun yang ingin dikomunikasikan oleh para pelajar kami, apa pun yang ingin mereka baca, adalah pokok bahasan kami” (Rivers, 1976). 
Oleh sebab itu, dapat dikatakan bahwa pembelajaran bahasa adalah fondasi di mana keterampilan akademis lainnya dibangun (Hassen, 2015). Berdasarkan hal itu, meningkatkan minat dan motivasi membaca siswa merupakan hal utama. Menjadikan kegiatan literasi dalam pembelajaran bahasa dan memfokuskan proses keterampilan berbahasa dapat secara langsuang membuat siswa menda-patkan pengetahuan apa saja. Misalnya, pengetahuan lingkungan dari teks dengan tema lingkungan; pengetahuan budaya dari teks dengan tema budaya, dan beragam tema teks lainnya.

Berdasarkan hasil dari angket yang diisi siswa, secara umum, siswa lebih menyukai membaca karya sastra (novel dan puisi) dari pada buku pelajaran dan surat kabar. Hal itu membuktikan bahwa siswa cenderung menyukai bahan bacaan yang menghibur di waktu luang mereka. Secara umum, siswa cenderung membaca untuk membuat tugas yang ditugaskan guru, jika tidak ada tugas, siswa cenderung tidak membaca. Dari segi kebermanfaatan kegiatan membaca, siswa secara umum merasakan bahwa membaca dapat menam-bah ilmu pengetahuan dan pengetahuan siswa tersebut meningkat.

Permasalahan yang perlu disoroti dari pelaksanaan GLS di sekolah yang diteliti adalah sebagai berikut. (1) Siswa cenderung hanya membaca ketika di sekolah, kegiatan membaca di rumah dilakukan jika ada tugas yang diberikan. (2) Semua siswa belum tertarik untuk membaca. Hal itu terlihat dari banyaknya kunjungan ke perpustakaan. (3) Pelaksa-naan GLS di awal pembelajaran hanya dijalankan oleh guru yang mengajar di jam pertama, sedangkan yang lain tidak. (4) Sekolah tidak berupaya melibatkan publik (orang tua, alumni, dan elemen masyarakat) untuk mengembangkan kegiatan literasi sekolah. (5) Adanya salah persepsi dengan pelaksanaan GLS, antara lain kegiatan literasi dengan membaca Al-Quran dan hafalan ayat, tidak ada kegiatan literasi pada kegiatan pembelajaran, kegiatan literasi pada KD tertentu, dan hanya guru tertentu yang terlibat pada kegiatan literasi. Berdasarkan permasala-han tersebut perlu solusi agar persepsi dan paradigma siswa dan guru mengenai literasi lebih luas.

\section{SIMPULAN}

Reformasi, inovasi, revisi, atau perubahan kurikulum sesuatu hal yang perlu dilakukan jika kurikulum yang digunakan saat ini tidak dapat mengimbangi dengan kebutuhan siswa. Salah satu rekomendasi untuk kurikulum yang dapat digunakan adalah dengan menggunakan literasi sebagai kurilum sekolah. Khususnya untuk pembelajaran bahasa, maka literasi yang dilakukan adalah literasi baca dan tulis. Untuk mewujudkan keberhasilan kurikulum tersebut, salah satu yang penting dilakukan adalah adanya keterlibatan guru.

Untuk memandu perancang kurikulum dalam upaya mempromosikan inovasi kurikulum. Pertama, inovasi perlu diperkenalkan secara bertahap dengan cara yang sistematis, yang dikembangkan di bawah terang isu-isu teoritis. Kedua, semua peserta harus dilibatkan dalam pengambilan keputusan dengan penyediaan maksimum untuk pengembangan konsensus, komitmen dan motivasi. Ketiga, keterlibatan administratif yang efektif dan dukungan diperlukan untuk pengembangan kurikulum untuk mencapai koherensi di antara komponenkomponennya. Guru, sebagai pemain utama, perlu diberikan dukungan administratif yang memadai tidak hanya selama tahap awal proses pembaharuan kurikulum, tetapi juga selama periode pengajaran berikutnya untuk memungkinkan perubahan diterapkan dalam praktik mengajar mereka. Akhirnya, komunikasi internal yang efisien perlu dipelihara dengan pengadopsi inovasi yang potensial untuk memfasilitasi penerimaan perubahan (Kırkgöz, 2009). 


\section{DAFTAR PUSTAKA}

Aydin, H., Ozfidan, B., \& Carothers, D. (2017). Meeting the Challenges of Curriculum and Instruction in School Settings in the United States. Journal of Social Studies Education Research, 8(3), 76-92.

Barnet, R., \& Coate, K. (2015). Engaging the Curriculum in Higher Education. Maidenhead: Open University Press and McGraw Hill Education.

Bumen, N. T., Cakar, E., \& Yildiz, D. G. (2014). Curriculum Fidelity and Factors Affecting Fidelity in the Turkish Context. Educational Sciences: Theory and Practice, 14(1), 219228 .

Burns, R. W., Yendol-Hoppey, D., \& Jacobs, J. (2015). High-Quality Teaching Requires Collaboration: How Partnerships Can Create a True Continuum of Professional Learning for Educators. Paper presented at the The Educational Forum.

Clasquin-Johnson, M. G. (2016). Now and Then: Revisiting Early Childhood Teachers' Reactions to Curriculum Change. South African Journal of Childhood Education, 6(1), $1-9$.

Cooper, T. (2017). Curriculum Renewal: Barriers to Successful Curriculum Change and Suggestions for Improvement. Journal of Education and Training Studies, 5(11), 115128.

Dusenbury, L., Brannigan, R., Falco, M., \& Hansen, W. B. (2003). A Review of Research on Fidelity of Implementation: Implications for Drug Abuse Prevention in School Settings. Health education research, 18(2), 237-256.

Hassen, R. (2015). Implementation of online reading assesment of encourage reading interests. Canadian Center of Science and Education, English Language Teaching, 18(1), 197206.

Hoydalsvik, T. E. L. (2017). Co-Operation is Not Enough: Teacher Educators as Curriculum Developers in Times of Change. International Journal of Higher Education, 6(5), 7687.

Hubball, H., \& Burt, H. (2014). An Integrated Approach to Developing and Implementing Learning-Centred Curricula. International Journal for Academic Development, 9(1), 51-65.

Jackson, J. (2005). An Inter-University, Cross-Disciplinary Analysis of Business Education: Perceptions of Business Faculty in Hong Kong. English for Specific Purposes, 24(3), 293-306.

Kurkgöz, Y. (2009). The Challenge of Developing and Maintaining Curriculum Innovation at Higher Education. Procedia-Social and Behavioral Sciences, 1(1), 73-78.

Longhurst, M. J. (2016). Curriculum Renewal in a Small Island State: Stabilization and Early Recovery Phases of Reconstruction. International Education Journal: Comparative Perspectives, 15(4), 66-85.

McGowan, U. (2018). Integrated Academic Literacy Development: Learner-Teacher Autonomy for MELTing the Barriers. Journal of University Teaching \& Learning Practice, 15(4), 6.

Musfiroh, T., \& Listyorini, B. (2016). Konstruk Kompetensi Literasi untuk Siswa Sekolah Dasar. LITERA, 15(1).

Nhlapo, M. D., \& Maharajh, L. R. (2017). Engaging Foreign Curriculum Experts in Curriculum Design: A Case Study of Primary School Curriculum Change in Lesotho. Universal Journal of Educational Research, 5(10), 1741-1747.

OECD. (2016). PISA 2015 Results in Focus. from http://www.oecd.org/pisa/pisa-2015-resultsin-focus.pdf 
Perry, K. H., \& Homan, A. (2014). "What I Feel in My Heart" Literacy Practices of and for the Self Among Adults With Limited or No Schooling. Journal of Literacy Research, 46(4), 422-454.

Petrone, R. (2013). Linking Contemporary Research on Youth, Literacy, and Popular Culture with Literacy Teacher Education. Journal of Literacy Research, 45(3), 240-266.

Pinto, L., Boler, M., \& Norris, T. (2007). Literacy is Just Reading and Writing, isn't it? the Ontario Secondary School Literacy Test and its Press Coverage. Policy Futures in Education, 5(1), 84-99.

PIRLS. (2011). International report. performance at the PIRLS 2011. Lynch School of Education, Boston College: International Benchmarks TIMMS \& PIRLS Report International Study Center (IEA).

Psifidou, I. (2009). Innovation in School Curriculum: the Shift to Learning Outcomes. Procedia-Social and Behavioral Sciences, 1(1), 2436-2440.

Purcell-Gates, V., Anderson, J., Gagne, M., Jang, K., Lenters, K. A., \& McTavish, M. (2012). Measuring Situated Literacy Activity: Challenges and Promises. Journal of Literacy Research, 44(4), 396-425.

Rahanu, H., Georgiadou, E., Khan, N., Colson, R., Hill, V., \& Edwards, J. A. (2016). The Development of Student Learning and Information Lliteracy: A Case Study. Education for Information, 32(3), 211-224.

Ramberg, M. R. (2014). What Makes Reform Work?--School-Based Conditions as Predictors of Teachers' Changing Practice after a National Curriculum Reform. International Education Studies, 7(6), 46-65.

Rekkor, S., Ümarik, M., \& Loogma, K. (2013). Adoption of National Curricula by Vocational Teachers in Estonia. Journal of Vocational Education \& Training, 65(4), 489-506.

Rivers, W. (1976). Speaking in Many Tongues: Essay in Foreign Language Teaching. Rowley: MA Newbury House.

Rogers, T., Tyson, C., \& Marshall, E. (2000). Living Dialogues in One Neighborhood: Moving Toward Understanding Across Discourses and Practices of Literacy and Schooling. Journal of Literacy Research, 32(1), 1-24.

Rumahlatu, D., Huliselan, E. K., \& Takaria, J. (2016). An Analysis of the Readiness and Implementation of 2013 Curriculum in the West Part of Seram District, Maluku Province, Indonesia. International Journal of Environmental and Science Education, $11(12), 5662-5675$.

Solikhah, I. (2015). Reading and Writing as Academic Literacy in EAP Program of Indonesian Leaners. Dinamika Ilmu: Jurnal Pendidikan, 15(2), 325-341.

Street, B. (2003). What's "new" in New Literacy Studies? Critical Approaches to Literacy in Theory and Practice. Current issues in comparative education, 5(2), 77-91.

Suryaman, M. (2015). Analisis Hasil Belajar Peserta Didik dalam Literasi Membaca melalui Studi Internasional (PIRLS) 2011. LITERA, 14(1), 170-186.

Tavdgiridze, L. (2016). Literacy Competence Formation of the Modern School. Journal of Education and Practice, 7(26), 107-110.

UNESCO. (2015). Literacy. from http://www.unesco.org/new/en/education/themes/educationbuildingblocks/literacy/

Uztozun, M. S., \& Troudi, S. (2015). Lecturers' Views of Curriculum Change at English Language Teaching Departments in Turkey. Novitas-ROYAL (Research on Youth and Language, 9(1), 15-29.

Wingate, U. (2012). Using Academic Literacies and Genre-Based Models for Academic Writing Instruction: A 'Literacy' Journey. Journal of English for Academic Purposes, 11(1), 26-37. 
Young, M. (2014). What is a Curriculum and What Can it Do? Curriculum Journal, 25(1), 713. 